\title{
Comparison of mineral content of bottled spring and mineral waters marketed in Turkey
}

\author{
Şeref Turhan ${ }^{1, a}$, Aslı Kurnaz ${ }^{1, b, *}$, Aybaba Hançerlioğulları, ${ }^{1, c}$ \\ ${ }^{1}$ Faculty of Science and Letters, Kastamonu University, 37150 Kastamonu, Turkey \\ *Corresponding author \\ A R T I C L E IN F O A B S T R A C T \\ Research Article \\ Drinking water is the most indispensable substance for humans. Bottled drinking waters are \\ preferred over tap water with the belief that they are more nutritious, better quality, more delicious \\ and safe in terms of health. Therefore, the Turkish bottled (spring and mineral) water market has \\ experienced a continuous growth since 2003, as in the whole world. This study focuses on \\ Received : 31/05/2021 \\ Accepted : 18/08/2021 \\ comparing the common mineral cation calcium $\left(\mathrm{Ca}^{2+}\right)$, magnesium $\left(\mathrm{Mg}^{2+}\right)$ and sodium $\left(\mathrm{Na}^{+}\right)$ \\ content of twenty one popular bottled spring and mineral water brands marketed in Turkey by using \\ an inductively coupled plasma optical emission spectrometry (ICP-OES). The average \\ concentrations of $\mathrm{Ca}, \mathrm{Mg}$ and $\mathrm{Na}$ analyzed in bottled spring and mineral water samples were found \\ as $14.9,24.1$ and $8.2 \mathrm{mg} / \mathrm{L}$ and $147.9,44.3$ and $117.3 \mathrm{mg} / \mathrm{L}$, respectively. This comparison confirms \\ Keywords: \\ that bottled natural mineral water has better quality in terms of major nutrient minerals than bottled \\ Bottled mineral water $\quad$ natural spring waters.
}

Bottled spring water

Major nutrient

Sodium

Magnesium

\section{Introduction}

Drinking water, which has many important roles such as hydro-electrolytic, acid-base and thermal balance, dissolution, digestion, absorption and disposal of nutrients in consumed foods, is an essential food source for humans (Petraccia et al., 2006). However, the rapid increase in the population and the growth of human activities that can cause contamination significantly increase the demand for providing adequate and safe sources of drinking water.

The impressive increase in the consumption of bottled water worldwide is due to consumers' concerns about increased water pollution and their objections to offensive flavors and odors such as chlorine and bacterial contamination from municipal water supplies (Güler, 2007). Another reason is the common belief that bottled mineral waters contain nutritious minerals and have beneficial therapeutic and medicinal influences (Seid et al., 2020). Bottled drinking water industries have been established to achieve this balance of supply and demand. Consequently, the bottled water global markets are constantly growing to meet the increase in demand and the search of quality drinking water. While the global average annual bottled drinking water (generally bottled natural mineral water) consumption per capita is $24.2 \mathrm{~L}$, this value is $105 \mathrm{~L}$ in the European Union (Bityukova and Petersell, 2010). In 2020, Turkey's bottled drinking water production reached to $10.5 \times 10^{9} \mathrm{~L}$ and annual bottled drinking water consumption per capita is $126 \mathrm{~L}$ (SUDER, 2021). Although Turkey has a great potential for natural mineral waters, mineral water consumption in Turkey is significantly lower compared to the European Union (Mertoğlu et al., 2003). However, with the introduction of bottled natural fruitflavored mineral waters in the market in 2002, bottled mineral water consumption per capita reached $7.6 \mathrm{~L}$ (Cemek et al., 2007; Gümüş et al., 2020).

Bottled drinking waters are supplied from many sources, such as aquifers, reservoirs, springs, and highly mineralized springs (Kurnaz et.al., 2016; Al Aamri and Ali, 2017; Mutlu and Kurnaz, 2017; Mutlu and Kurnaz, 2018; Mutlu, 2019; Mutlu, 2021). The chemical composition of bottled spring and mineral waters depends on the local 
geology of the source area and the geochemistry of rocks in contact with water (Daniele et al., 2019). Therefore, depending on their sources, bottled waters include different amounts of macro and microelements such as calcium $(\mathrm{Ca})$, magnesium $(\mathrm{Mg})$, sodium $(\mathrm{Na})$, potassium $(\mathrm{K})$, manganese $(\mathrm{Mn})$, iron $(\mathrm{Fe})$, copper $(\mathrm{Cu})$, zinc $(\mathrm{Zn})$, etc. that significantly affect living organisms (Bertoldi et al., 2011; Kończyk et al., 2019). $\mathrm{Ca}, \mathrm{Mg}$ and $\mathrm{Na}$ are essential nutrients for human health. More than $99 \%$ of total body $\mathrm{Ca}$ is found in bones and teeth where it functions as an important structural element. The remaining body $\mathrm{Ca}$ functions in metabolism serves as a signal for vital physiological processes including blood clotting, vascular contraction, muscle contraction, blood clotting and nerve transmission (WHO, 2009). Mg is the fourth most abundant cation in the human body and the second most abundant cation in the intracellular fluid. $\mathrm{Mg}$ is a cofactor of about 350 cellular enzymes. $\mathrm{Mg}$ is needed for insulin sensitivity and normal vascular tone (WHO, 2009). Na is fundamental regulation of cell permeability and body fluids. Na deficiency is rare, but an excessive intake may be associated with high blood pressure (Quattrini et al., 2016). The ideal bottled water should be rich in $\mathrm{Ca}$ and $\mathrm{Mg}$ and have low Na content. However, no definite conclusions can be drawn concerning the possible association between $\mathrm{Na}$ in mineral water and the occurrence of hypertension but $\mathrm{Na}$ concentrations in excess of $200 \mathrm{mg} \mathrm{L}^{-1}$ may cause an unacceptable taste (Kończyk et al., 2019).

While the concentrations of $\mathrm{Ca}, \mathrm{Mg}$ and $\mathrm{Na}$ in bottled drinking water vary significantly from one source to another, mineral-rich drinking water may make significant contributions to the total intakes of these nutrients in some populations or population subgroups (WHO, 2009). Therefore, bottled water should be supported by accurate information about their chemical composition. In particular, the chemical composition and related properties of mineral waters are not only important for health, but also for the promotion and advertising of these waters (Kończyk et al., 2019). Up to now, many studies have focused on the chemical quality of bottled drinking and mineral waters consumed in various countries and Turkey (Mahajan et al., 2006; Cemek et al., 2007; Baba et al., 2008; Güler and Alpaslan, 2009; Cicchella et al., 2010; Cengiz et al., 2015; Dos Santos et al. 2016; Khandaker et al., 2017; Dippong et al., 2020; Todorović et al., 2020). However, the contents $\mathrm{Ca}, \mathrm{Mg}$ and $\mathrm{Na}$ in bottled spring and mineral waters commercially sold in Turkey have not been compared. Having in mind the fact mentioned above, the purposes of the study is to: (1) analyze major minerals ( $\mathrm{Ca}, \mathrm{Mg}$ and $\mathrm{Na}$ ) in forty-two bottled water (twenty-one springs and twentyone minerals) brands commercially available on Turkish market and (2) compare the concentration of $\mathrm{Ca}, \mathrm{Mg}$ and $\mathrm{Na}$ in these brands of bottled spring and mineral water.

\section{Material and Methods}

\section{Collection and Preparation of Bottled Water Samples}

In Turkey, most of the bottled natural mineral waters are sold in $0.2,0.25$ and $0.330 \mathrm{~L}$ volumes of metal screwcap glass bottles, while bottled natural spring waters are sold in 0.5, 1.5 and $5 \mathrm{~L}$ plastic bottles made of polyethylene terephthalate (PET). Forty-two bottled water brands chosen for this study represent the highest selling and most consumed brands on daily basis by the Turkish population. Twenty-one brands of bottled spring water and twenty-one brands of bottled mineral water available on the Turkish market were purchased in randomly selected supermarkets in Ankara, the capital city of Turkey.

All bottled water samples were kept at room temperature until analysis and each water sample was opened in the laboratory. Each bottled spring water sample was filtered from microfilters so that no particles were left, and then it was taken into the analysis process without any process (Alzaridi and Kurnaz, 2020). Whereas each bottled mineral water sample was degassed by using an ultrasonic bath for 15 minutes at room temperature. All reagents used for analyses were of analytical grade.

\section{Instrumental Analysis}

The concentration of cations $\left(\mathrm{Ca}^{+2}, \mathrm{Mg}^{+2}\right.$ and $\left.\mathrm{Na}^{+}\right)$were analyzed by the Spectroblue ICP-OES system equipped with Spectro's proprietary ICP Analyzer Pro software in the Central Laboratory of Kastamonu University. Details of the ICP-OES system are given in the study performed by Alzaridi and Kurnaz (2020). The ICP-OES instrument was used at $1.2 \mathrm{~kW}$ plasma power and the gas flows in the auxiliary and nebulizer were maintained at $0.8 \mathrm{~L} \mathrm{~min}^{-1}$. Each of the measurements was set to repeat three-times. Calibration solutions were prepared by diluting the certified standard ICP TraceCert mix solutions containing 33 elements purchased from Sigma-Aldrich. Calibration of the ICP-OES system was carried out at the beginning of the measurements and the correlation coefficients were higher than 0.999 for all analytes.

\section{Results and discussion}

The concentrations of major cations analyzed in bottled spring or drinking water (BDW) samples and bottled mineral water (BMW) samples are given in Table 1 and Table 2, respectively. Frequency distributions of the concentrations of $\mathrm{Ca}, \mathrm{Mg}$ and $\mathrm{Na}$ in $\mathrm{BDW}$ and $\mathrm{BMW}$ samples are given in Figure 1 and Figure 2, respectively. Table 3 compares the average concentration of these major cations analyzed in the studied BDW and BMW samples with those analyzed in BDW and BMW samples consumed in various countries.

It can be seen from Table 1 that the order of major minerals analyzed in the studied BDW samples is $\mathrm{Mg}>\mathrm{Ca}$ $>\mathrm{Na}$ according to their average concentration values. As can be seen from Figure 1, the frequency distributions of the concentration of $\mathrm{Ca}$ and $\mathrm{Na}$ exhibit a log-normal distribution while the frequency distribution of the concentration of $\mathrm{Mg}$ exhibits non-normal distribution. The concentration of $\mathrm{Ca}$ varied from 1.9 to $31.9 \mathrm{mg} / \mathrm{L}$ with an average of $14.9 \mathrm{mg} / \mathrm{L}$. The highest $\mathrm{Ca}$ concentration was analyzed in the BDW3 coded brand, the lowest $\mathrm{Ca}$ concentration was analyzed in the BDW15 coded brand. From Table 3, the average Ca content is higher than those analyzed in BDW samples consumed in Malaysia, Romania, Oman, Bangladesh, and South Korea while it is lower than those in BDW samples consumed in Chile, Germany, Croatia, Spain, Iran, and India. The concentration of $\mathrm{Mg}$ varied from 0.4 to $49.7 \mathrm{mg} / \mathrm{L}$ with an average of $24.1 \mathrm{mg} / \mathrm{L}$. The highest $\mathrm{Mg}$ concentration was analyzed in the BDW14 coded brand, the lowest $\mathrm{Mg}$ concentration was analyzed in the BDW15 coded brand. 
Table 1. Concentrations of major cations analyzed in bottled spring water samples

\begin{tabular}{|c|c|c|c|}
\hline \multirow{2}{*}{ Sample ID } & \multicolumn{3}{|c|}{ Concentration (mg/L) } \\
\hline & $\mathrm{Ca}$ & $\mathrm{Mg}$ & $\mathrm{Na}$ \\
\hline BDW1 & 9.1 & 5.7 & 1.7 \\
\hline BDW2 & 9.9 & 38.1 & 2.5 \\
\hline BDW3 & 31.9 & 18.9 & 3.7 \\
\hline BDW4 & 17.8 & 48.3 & 5.7 \\
\hline BDW5 & 15.0 & 34.1 & 5.9 \\
\hline BDW6 & 15.8 & 34.5 & 5.9 \\
\hline BDW7 & 22.3 & 35.1 & 3.8 \\
\hline BDW8 & 7.7 & 12.1 & 4.3 \\
\hline BDW9 & 7.6 & 19.1 & 5.3 \\
\hline BDW10 & 10.7 & 37.4 & 4.0 \\
\hline BDW11 & 19.9 & 27.4 & 2.7 \\
\hline BDW12 & 25.5 & 49.7 & 3.8 \\
\hline BDW13 & 23.8 & 39.2 & 6.4 \\
\hline BDW14 & 13.7 & 49.7 & 12.1 \\
\hline BDW15 & 1.9 & 3.5 & 2.5 \\
\hline BDW16 & 10.9 & 22.9 & 76.1 \\
\hline BDW17 & 12.6 & 21.9 & 13.9 \\
\hline BDW18 & 14.1 & 0.4 & 0.7 \\
\hline BDW19 & 9.9 & 3.7 & 4.3 \\
\hline BDW20 & 26.2 & 2.7 & 4.7 \\
\hline BDW21 & 6.4 & 1.0 & 1.6 \\
\hline Average & 14.9 & 24.1 & 8.2 \\
\hline Standard error & 1.7 & 3.7 & 3.5 \\
\hline Median & 13.7 & 22.9 & 4.3 \\
\hline Standard deviation & 7.6 & 17.0 & 15.9 \\
\hline Kurtosis & -0.2 & -1.4 & 19.1 \\
\hline Skewness & 0.6 & 0.0 & 4.3 \\
\hline Min & 1.9 & 0.4 & 0.7 \\
\hline Max & 31.9 & 49.7 & 76.1 \\
\hline
\end{tabular}

Table 2. Concentrations of major cations analyzed in bottled mineral water samples

\begin{tabular}{|c|c|c|c|}
\hline \multirow{2}{*}{ Sample ID } & \multicolumn{3}{|c|}{ Concentration $(\mathrm{mg} / \mathrm{L})$} \\
\hline & $\mathrm{Ca}$ & $\mathrm{Mg}$ & $\mathrm{Na}$ \\
\hline BMW1 & 190.8 & 20.7 & 6.4 \\
\hline BMW2 & 31.3 & 5.1 & 10.1 \\
\hline BMW3 & 43.0 & 82.6 & 73.5 \\
\hline BMW4 & 52.0 & 8.9 & 543.0 \\
\hline BMW5 & 65.4 & 24.7 & 640.4 \\
\hline BMW6 & 123.9 & 3.7 & 3.8 \\
\hline BMW7 & 22.9 & 4.3 & 23.2 \\
\hline BMW8 & 198.8 & 120.8 & 217.5 \\
\hline BMW9 & 393.1 & 30.1 & 12.0 \\
\hline BMW10 & 177.6 & 102.2 & 104.8 \\
\hline BMW11 & 59.8 & 28.7 & 26.7 \\
\hline BMW12 & 180.9 & 34.7 & 18.5 \\
\hline BMW13 & 131.0 & 45.2 & 124.8 \\
\hline BMW14 & 175.5 & 102.1 & 105.5 \\
\hline BMW15 & 143.9 & 82.1 & 86.0 \\
\hline BMW16 & 302.7 & 44.6 & 143.2 \\
\hline BMW17 & 102.0 & 26.7 & 91.8 \\
\hline BMW18 & 221.5 & 82.8 & 80.7 \\
\hline BMW19 & 8.9 & 1.4 & 4.4 \\
\hline BMW20 & 189.8 & 33.9 & 22.9 \\
\hline BMW21 & 208.3 & 45.8 & 125.0 \\
\hline Average & 143.9 & 44.3 & 117.3 \\
\hline Standard error & 21.2 & 8.0 & 36.7 \\
\hline Median & 143.9 & 33.9 & 80.7 \\
\hline Standard deviation & 97.0 & 36.5 & 168.4 \\
\hline Kurtosis & 0.7 & -0.6 & 5.6 \\
\hline Skewness & 0.7 & 0.7 & 2.4 \\
\hline Min & 8.9 & 1.4 & 3.8 \\
\hline Max & 393.1 & 120.8 & 640.4 \\
\hline
\end{tabular}



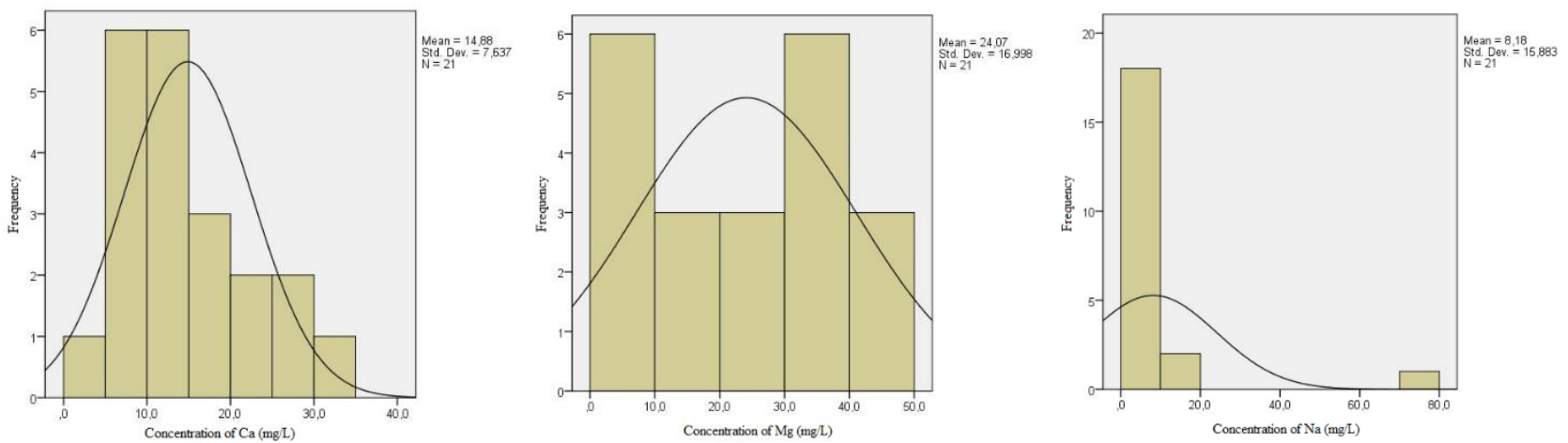

Figure 1. Frequency distributions of the concentrations of $\mathrm{Ca}, \mathrm{Mg}$ and $\mathrm{Na}$ in the studied bottled spring waters
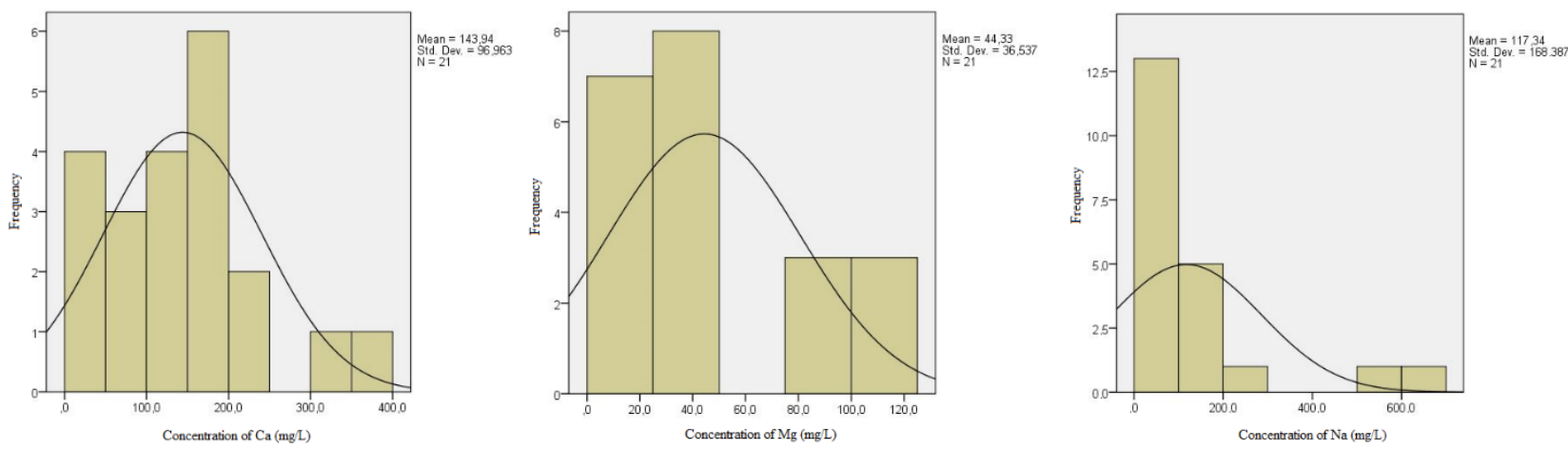

Figure 2. Frequency distributions of the concentrations of $\mathrm{Ca}, \mathrm{Mg}$ and $\mathrm{Na}$ in the studied bottled mineral waters

Table 3. Comparison of the average concentration of major cations with the literature values

\begin{tabular}{l|llllll}
\hline Water type & $\mathrm{N}$ & Origin & $\mathrm{Ca}$ & $\mathrm{Mg}$ & $\mathrm{Na}$ & Reference \\
\hline BDW & 10 & Chile & 36 & 8 & 25 & Daniele et al., 2019 \\
BDW & 908 & Germany & 91 & 22 & 20 & Birke et al., 2010 \\
BDW & 10 & Croatia & 57 & 17 & 3 & Peh et al., 2010 \\
BDW & 13 & Spain & 42 & 14 & 45 & Platikanov et al., 2017 \\
BDW & 20 & Iran & 33 & 12 & 17 & Kermanshahi et al., 2010 \\
BDW & 10 & Malaysia & 0,4 & 0,3 & 0,7 & Aris et al., 2013 \\
BDW & 14 & Romania & 4 & 4 & 2 & Dippong et al., 2020 \\
BDW & 17 & Oman & 13 & 10 & 12 & Al Aamri et al., 2017 \\
BDW & 17 & India & 17 & 8 & 23 & Mahajan et al., 2006 \\
BDW & 14 & Bangladesh & 0.04 & 0.01 & 0.29 & Rahman et al., 2017 \\
BDW & 35 & South Korea & 0.5 & 0.2 & 0.3 & Bong et al., 2009 \\
BDW & 21 & Turkey & 15 & 24 & 8 & This study \\
BMW & 186 & Italy & 69 & 13 & 20 & Cicchella et al., 2010 \\
BMW & 9 & Malaysia & 41 & 10 & 11 & Khandaker et al., 2017 \\
BMW & 14 & Egypt & 20 & 8 & 31 & Yousef, 2018 \\
BMW & 9 & Serbia & 46 & 22 & 33 & Jankovic' et al., 2012 \\
BMW & 86 & British Isles & 46 & 8 & 18 & Smedley, 2010 \\
BMW & 47 & Poland & 82 & 26 & 44 & Astel et al., 2014 \\
BMW & 5 & Estonia & 69 & 23 & 212 & Bityukova and Petersell, 2010 \\
BMW & 21 & Romania & 107 & 27 & 47 & Levei et al., 2016 \\
BMW & 571 & EU & 67 & 16 & 15 & Bertoldi et al., 2011 \\
BMW & 9 & Ethiopia & 13 & 6 & 38 & Seda et al., 2013 \\
BMW & 22 & Nordic & 6 & 11 & 12 & Frengstad et al., 2010 \\
BMW & 53 & Iran & 50 & 12 & 8 & Kermanshahi et al., 2010 \\
BMW & 35 & Slovenia & 120 & 104 & 218 & Brenčič et al., 2010 \\
BMW & 21 & Turkey & 144 & 44 & 117 & This study \\
\hline
\end{tabular}

From Table 3, the average Mg content is higher than those analyzed in BDW samples consumed in all countries. The concentration of $\mathrm{Na}$ varied from 0.7 to $76.1 \mathrm{mg} / \mathrm{L}$ with an average of $8.2 \mathrm{mg} / \mathrm{L}$. The highest $\mathrm{Na}$ concentration was analyzed in the BDW18 coded brand, the lowest $\mathrm{Na}$ concentration was analyzed in the BDW16 coded brand.
From Table 3, the average Na content is higher than those analyzed in BDW samples consumed in Croatia, Malaysia, Romania, Bangladesh, and South Korea while it lower than those in BDW samples consumed in Chile, Germany, Spain, Iran, Oman, and India. 
It can be seen from Table 2 that the order of major minerals analyzed in the studied BMW samples is $\mathrm{Ca}>\mathrm{Na}$ $>\mathrm{Mg}$ according to their average concentration values. As can be seen from Figure 1, the frequency distributions of the concentration of $\mathrm{Mg}$ and $\mathrm{Na}$ exhibit a log-normal distribution while the frequency distribution of the concentration of $\mathrm{Ca}$ exhibits near-normal distribution. The concentration of Ca varied from 8.9 to $393.1 \mathrm{mg} / \mathrm{L}$ with an average of $143.9 \mathrm{mg} / \mathrm{L}$. The highest Ca concentration was analyzed in the BMW9 coded brand, the lowest $\mathrm{Ca}$ concentration was analyzed in the BMW19 coded brand. The average concentration of $\mathrm{Ca}$ is approximately ten times higher than that analyzed in the studied BDW samples. From Table 3, the average Ca content is higher than those analyzed in BMW samples consumed in various countries. The concentration of $\mathrm{Mg}$ varied from 1.4 to $120.87 \mathrm{mg} / \mathrm{L}$ with an average of $44.3 \mathrm{mg} / \mathrm{L}$. The highest $\mathrm{Mg}$ concentration was analyzed in the BMW8 coded brand, the lowest $\mathrm{Mg}$ concentration was analyzed in the BMW19 coded brand. The average concentration of $\mathrm{Mg}$ is approximately two times higher than that analyzed in the studied BDW samples. From Table 3, the average $\mathrm{Mg}$ content is higher than those analyzed in BMW samples consumed in all countries except for Slovenia. The concentration of Na varied from 3.8 to $640.4 \mathrm{mg} / \mathrm{L}$ with an average of $117.3 \mathrm{mg} / \mathrm{L}$. The highest $\mathrm{Na}$ concentration was analyzed in the BMW5 coded brand, the lowest $\mathrm{Na}$ concentration was analyzed in the BMW6 coded brand. The average concentration of $\mathrm{Na}$ is approximately fourteen times higher than that analyzed in the studied BDW samples. From Table 3, the average Na content is higher than those analyzed in BMW samples consumed in all countries except for Estonia and Slovenia.

\section{Conclusion}

A comparison of the average values of the major minerals in the bottled spring and mineral waters revealed that the concentrations of $\mathrm{Ca}, \mathrm{Mg}$, and $\mathrm{Na}$ are 2 to 14 times higher in the bottled mineral waters compared to spring waters. This differentiation in average concentrations of major minerals is anticipated because natural mineral waters are mostly supplied from areas near geothermal regions with deep groundwater circulation patterns and recent tectonic/volcanic activity.

\section{References}

Al Aamri ZM, Ali BH. 2017. Chemical composition of different brands of bottled drinking water sold in Oman as labelled by manufacturers. Asian Journal of Water, Environment and Pollution, 14(3):1-7.

Alzaridi FMNS, Kurnaz A. 2020. Determination of concentration levels of toxic elements and radon in drinking waters consumed in Kastamonu province, Turkey. International Journal of Environmental Analytical Chemistry, DOI: https://doi.org/10.1080/03067319.2020.1849664.

Aris AZ, Kam RCY, Lim AP, Praveena SM. 2013. Concentration of ions in selected bottled water samples sold in Malaysia. Applied Water Science, 3:67-75.

Astel A, Michalski R, Łyko A, Jabłońska-Czapla M, Bigus K, Szopa S, Kwiecińsk A. 2014. Characterization of bottled mineral waters marketed in Poland using hierarchical cluster analysis. Journal of Geochemical Exploration, 143:136-145.
Baba A, Ereeş FS, Hiçsönmez Ü, Çam S, Özdilek HG. 2008. An assessment of the quality of various bottled mineral water marketed in Turkey. Environmental Monitoring and Assessment, 139:277-285.

Bertoldi D, Bontempo L, Larcher R, Nicolini G, Voerkelius S, Lorenz GD, Ueckermann H, Froeschl H, Baxter MJ, Hoogewerff J, Brereton P. 2011. Survey of the chemical composition of 571 European bottled mineral waters. Journal of Food Composition and Analysis, 24 (3): 376-385.

Birke M, Rauch U, Harazim B, Lorenz H, Glatte W. 2010. Major and trace elements in German bottled water, their regional distribution, and accordance with national and international standards. J Journal of Geochemical Exploration, 107(3):245-271.

Bityukova L, Petersell V. 2010. Chemical composition of bottled mineral waters in Estonia. Journal of Geochemical Exploration, 107:238-244.

Bong YS, Ryu JS, Lee KS. 2009. Characterizing the origins of bottled water on the South Korean market using chemical and isotopic compositions. Analytica Chimica Acta, 631(2):189-195.

Brenčič M, Ferjan T, Gosar M. 2010. Geochemical survey of Slovenian bottled waters. Journal of Geochemical Exploration, 107(3):400-409.

Cemek M, Akkaya L, Birdan YO, Seyrek K, Bulut S, Konuk M. 2007. Nitrate and nitrite levels in fruity and natural mineral waters marketed in western Turkey. Journal of Food

Composition and Analysis, 20:236-240.

Cengiz MF, Durak MZ, Nilufer S, Bilgin AK. 2015. Ion chromatographic determination of free cyanide in different classes of bottled natural mineral water consumed in Turkey. International Journal of Food Properties, 18, 746-756.

Cicchella D, Albanese S, De Vivo B, Dinelli E, Giaccio L, Lima A, Valera P. 2010. Trace elements and ions in Italian bottled mineral waters: Identification of anomalous values and human health related effects. Journal of Geochemical Exploration, 107:336-349.

Daniele L, Cannatelli C, Buscher JT, Bonatici G. 2019. Chemical composition of Chilean bottled waters: Anomalous values and possible effects on human health. Science of the Total Environment, 689:526-533.

Dippong T, Hoaghia MA, Mihali C, Cical E, Calugaru M. 2020. Human health risk assessment of some bottled waters from Romania. Environmental Pollution, 267(115409):1-15.

Dos Santos ÉJ, De Oliveira JDR, Hermann AB, Sturgeon RE. 2016. Chemical quality of bottled mineral waters from markets of Curitiba-PR-Brazil. Brazilian Archives of Biology and Technology, 59:1-24.

Frengstad BS, Lax K, Tarvainen T, Jæger Ø, Wigum BJ. 2010. The chemistry of bottled mineral and spring waters from Norway, Sweden, Finland and Iceland. Journal of Geochemical Exploration, 107:350-361.

Güler C. 2007. Characterization of Turkish bottled waters using pattern recognition methods. Chemometrics and Intelligent Laboratory Systems, 86:86-94.

Güler C, Alpaslan M. 2009. Mineral content of 70 bottled water brands sold on the Turkish market: Assessment of their compliance with current regulations. Journal of Food Composition and Analysis, 22:728-737.

Gümüş G, Destanoğlu O, Şimşek MG, Bakır TK, Turhan Ş. 2020. Assessment of concentrations of anions in bottled natural mineral waters from the Turkish market in accordance with national and international standards. International Journal of Environmental Analytical Chemistry, DOI: https://doi.org/10.1080/03067319.2021.1884239.

Janković MM, Todorović DJ, Todorović NA, Nikolov J. 2012. Natural radionuclides in drinking waters in Serbia. Applied Radiation and Isotopes, 70:2703-2710.

Kermanshahi KY, Tabaraki R, Karimi H, Nikorazm M, Abbasi S. 2010. Classification of Iranian bottled waters as indicated by manufacturer's labellings. Food Chemistry, 120:1218-1223. 
Khandaker MU, Nasir NLM, Zakirin NS, Abu Kassima H, Asaduzzaman K, Bradley DA, Zulkifli MY, Hayyan A. 2017. Radiation dose to the Malaysian populace via the consumption of bottled mineral water. Radiation Physics and Chemistry, 140:173-179.

Kończyk J, Muntean E, Gega J, Frymus A, Michalski R. 2019. Major inorganic anions and cations in selected European bottled waters. Journal of Geochemical Exploration, 197:2736.

Kurnaz A, Mutlu E, Uncumusaoğlu AA. 2016. Determination of Water Quality Parameters and Heavy Metal Content in Surface Water of Çiğdem Pond (Kastamonu/Turkey). Turkish Journal of Agriculture-Food Science and Technology 4(10): 907-913.

Levei EA, Hoaghia MA, Senila M, Miclean M, Tanaselia C, Carstea EM. 2016. Chemical composition of some Romanian bottled natural mineral waters. Studia UBB Chemia, 3(2):391-400.

Mahajan RK, Walia TPS, Lark BS, Sumanjit. 2006. Analysis of physical and chemical parameters of bottled drinking water. International Journal of Environmental Health Research, 16(2):89-98.

Mertoğlu O, Bakır N, Kaya T. 2003. Geothermal applications in Turkey. Geothermics, 32:419-428.

Mutlu E, Kurnaz A. 2017. Determination of seasonal variations of heavy metals and physicochemical parameters in Sak1z Pond (Kastamonu-Turkey). Fresenius Environmental Bulletin, 26(4):2807-2816.

Mutlu E, Kurnaz A. 2018. Assessment of physicochemical parameters and heavy metal pollution in Çeltek Pond water. Indian Journal of Geo-Marine Sciences, (IJMS), 47(06):1185-1192.

Mutlu E. 2019. Evaluation of spatio-temporal variations in water quality of Zerveli stream (northern Turkey) based on water quality index and multivariate statistical analyses. Environmental Monitoring and Assesment, June 2019, 191:335.

Mutlu E. 2021. Determination of Seasonal Variations of Heavy Metals and Physicochemical Parameters In Kildır Pond (Yıldızeli-Sivas). Fresenius Environmental Bulletin, 30(6):5573-5580.
Peh Z, Šorša A, Halamić J. 2010. Composition and variation of major and trace elements in Croatian bottled waters. Journal of Geochemical Exploration, 107: 227-237.

Petraccia L, Liberati G, Masciullo SG, Grassi M, Fraioli A. 2006. Water, mineral waters and health, Clinical Nutrition, 25:377385 .

Platikanov S, Hernández A, González S, Cortina JL,Tauler R, Devesa R. 2017. Predicting consumer preferences for mineral composition of bottled and tap water. Talanta, 162:1-9.

Quattrini S, Pampaloni B, Brandi ML. 2016. Natural mineral waters: chemical characteristics and health effects. Clinical Cases in Mineral and Bone Metabolism, 13(3):173-180.

Rahman IMM, Barua S, Barua R, Mutsuddi R, Alamgir M, Islam F, Begum ZA, Hasegawa H. 2017. Quality assessment of the non-carbonated bottled drinking water marketed in Bangladesh and comparison with tap water. Food Control, 73:1149-1158.

Seda T, Assefa M, Chandravanshi BS, Redi M. 2013. Levels of common ions in bottled mineral waters consumed in Addis Ababa, Ethiopia. Ethiopian Journal of Science, 36(1):27-40.

Seid AMA, Turhan Ş, Kurnaz A, Bakır TK, Hançerlioğulları A. 2020. Radon concentration of different brands of bottled natural mineral water commercially sold in Turkey and radiological risk assessment. International Journal of Environmental Analytical Chemistry, DOI: https://doi.org/10.1080/03067319.2020.1830989.

Smedley PL, 2010. A survey of the inorganic chemistry of bottled mineral waters from the British Isles. Applied Geochemistry, 25:1872-1888.

Todorović T, Đurović MĆ, Štrbački J, Papić P, 2020. Rare earth elements in mineral waters in Serbia. Environmental Earth Sciences, 79(290):1-12.

WHO (World Health Organization). 2009. Calcium and magnesium in drinking-water: public health significance, WHO Library Cataloguing-in-Publication Data, NLM classification: QV 276, Spain.

Yousef HA. 2018. Assessment of the annual effective dose of bottled mineral waters using closed can technique. Journal of Advances in Physics, 14(3):5696-5707. 